\title{
Manusia dan Kurikulum Pendidikan dalam Perspektif Filsafat Pendidikan Islam (Sebuah Kajian Aksiologis)
}

\author{
Firdaus* \\ Universitas Islam Riau, Indonesia \\ Jl. Kaharuddin Nst No.113, Simpang Tiga, Kec. Bukit Raya, Kota Pekanbaru, Riau 28284 \\ Email: firdausrida@edu.uir.ac.id
}

\begin{abstract}
This research was conducted to determine the relationship between humans and the curriculum and how to form the curriculum in accordance with human needs. Mistakes in the preparation of a curriculum will have a fatal impact on the actors of the curriculum. This research is a qualitative research with a library research approach. In this study, researchers found that in the preparation of a curriculum, it must refer to what is needed by humans. To answer what is needed by humans, it must be explored who the human being really is through the terms used in the Koran. Many terms are used by the Koran to denote human beings such as al-Ins, al-Insan, al-Basyar. Bani Adam. These terms provide influence and impact in curriculum preparation. Because if it does not start from this term in curriculum preparation, the curriculum itself will be of less use to students. Curriculum development based on human terminology according to the Koran will minimize errors in the preparation of the curriculum itself. By using a terminology approach that comes from the Koran, the curriculum will be in line with human nature. So that the educational curriculum accommodates human values that exist in humans.
\end{abstract}

\section{Keywords: Human, curriculum}

Abstrak: Peneitian ini dilakukan untuk mengetahui hubungan antara manusia dan kurikulum serta bagaimana bentuk kurikulum yang sesuai dengan kebutuhan manusia itu sendiri. Penelitian ini adalah penelitian kualitatif dengan pendekatan library research. Dalam penelitian ini peneliti menemukan bahwa dalam penyusunan sebuah kurikulum haruslah mengacu kepada apa yang dibutuhkan oleh manusia. Untuk menjawab apa yang dibutuhkan oleh manusia maka haruslah digali siapa manusia itu sebenarnya melalui term-term yang digunakan dalam Al-Quran. Banyak istilah yang digunakan Al-Quran untuk menunjukkan manusia seperti al-Ins, al-Insan, al-Basyar, Bani Adam. Term-term ini memberikan pengaruh dan dampak dalam penyusunan kurikulum. Karena jika tidak bertolak dari term ini dalam penyusunan kurikulum, kurikulum itu sendiri akan kurang bermanfaat bagi peserta didik. Penyusunan kurikulum yang berdasarkan terminolog manusia menurut Al-Quran akan dapat meminimalisir kesalahan dalam penyusunan kurikulum itu sendiri. Dengan menggunakan pendekatan terminology yang berasal dari Al-Quran, maka kurikulum tersebut akan sejalan dengan fitrah yang ada pada diri manusia itu sendiri. Sehingga kurikulum pendidikan tersebut dapat mengakomodir nilai-nilai insaniyah yang ada pada manusia.

Kata Kunci: Manusia, Kurikulum

Jurnal Pendidikan Agama Islam Al-Thariqah Vol. 5, No. 2, Juli - Desember 2020

Received: 05 September 2020; Accepted 17 December 2020; Published 21 December 2020

*Corresponding Author: firdausrida@edu.uir.ac.id 


\section{PENDAHULUAN}

Berbicara masalah pendidikan maka kita tidak akan terlepas dari membicarakan tentang kurikulum. Kurikulum merupakan suatu yang sangat urgens dalam instusi pendidikan. Dapat dikatakan bahwa sebuah lembaga pendidikan yang tidak memiliki kurikulum yang maka lembaga tersebut belumlah dapat kita katakan dengan lembaga pendidikan yang sempurna.

Begitu pentingnya kurikulum bagi sebuah pendidikan, maka para ahli banyak mengoreksi dan merivisi kurikulum pendidikan yang ada pada saat ini. Koreksian dan juga revisi terhadap kurikulum tersebut dilandasi oleh semangat dalam rangka memajukan pendidikan dan juga meningkatkan kualitas dari suatu bangsa.

Dalam perjalanannya kurikulum di Indonesia telah mengalamai beberapa kali perubahan. Perubahan-perubahan kurikulum tersebut dimulai pada tahun 1947, 1952, 1964, 1968, 1975, 1984, 1994, 2004, 2006 sampai pada akhirnya pada tahun 2013 (Ritonga, 2018: 88).

Perubahan-perubahan ataupun revisi kurikulum tersebut adalah sebuah konsekwensi logis dari perubahan politik, sosial budaya, ekonomi, ilmu pengetahuan dan tekhnologi dan juga pengaruh dari pasar bebas yang digembar-gemborkan pada saat ini. Hal tersebut juga merupakan suatu tuntutan dari masyarakat yang tidak pernah puas terhadaphasil pendidikan dan selalu ingin memperbaikinya (Asri, 2017: 192).

Suatu hal yang lumrah jika sebuah negara berkembang seperti Indonesia pada saat sekarang ini merubah-rubah kurikulum dalam rangka "mencari jati dirinya" dalam bidang pendidikan. Sejarah mencatat bahwa Indonesia mengalami perubahan kurikulum dalam waktu yang sangat cepat (Asri, 2017: 195).

Perubahan-perubahan kurikulum tersebut bukanlah suatu kenistaan. Boleh saja suatu negara merubah dan merevisi Kurikulum Pendidikan Nasionalnya dalam rangka karena kurikulum sebagai alat untuk mencapai tujuan hendaknya menyesuaikan dengan perkembangan yang ada dan terus menerus (Subiyantoro, 2015: 4-5).

Akan tetapi disisi lain perubahanperubahan kurikulum ini menjadikan sebuah kebingungan yang besar bagi guru dan juga peserta didik yang mana mereka secara langsung menjadi pelaku proses pendidikan tersebut. Sehingga timbullah suatu anekdot bahwa setiap pergantian menteri maka akan berganti pulalah kurikulum pendidikan.

Manusia adalah sebagai pelaku pendidikan. Manusia merupakan suatu subjek sekaligus objek dalam pendidikan tersebut. Sehingga dalam merumuskan kurikulum pendidikan haruslah memperhatikan "manusia" sebagai subjek dan objek dari pendidikan tersebut.

Al-Quran telah menjelaskan siapa manusia sebenarnya. Al-Quran menggunakan beberapa terminology untuk menunjukkan manusia secara keberadaannya dan juga dalam aspek psikologisnya.

Terminologi manusia yang terdapat dalam Al-Quran dapat dijadikan dasar dalam penyusunan kurikulum agar dapat menciptakan suatu pendidikan yang benar-benar memanusiakan manusia.

Hal tersebut penting untuk dilakukan agar lembaga pendidikan tersebut benar-benar suatu lembaga yang menyenangkan bagi siswa-siswinya dan menjadi suatu lembaga yang benar-benar dapat menghantarkan kepada cita-cita anak didiknya.

\section{KONSEP TEORI}

\section{Manusia}

Ketika Al-Quran membicarakan tentang manusia, maka Al-Quran menggunakan term yang berbeda-beda. Kadang kala Allah menggunakan katakata an-Nas untuk menunjukkan manusia. 
Akan tetapi ditempat yang lain Allah menggunakan kata al-Basyar, al Ins, Insan dan Bani Adam untuk menunjukkan keberadaan manusia.

Istilah-istilah manusia yang digunakan Al-Quran memiliki nuansa yang berbeda-beda. Perbedaan istilahistilah yang digunakan Al-Quran tersebut dikarenakan sudut pandang yang berbeda pula dalam memandang manusia sebagi ciptaan Allah SWT.

Manusia disebutkan Allah SWT dengan kata al-Ins. Kata al-Ins ini disebutkan berbarengan dengan kata Jinn yang menunjukkan bahwa manusia dan Jin tersebut ada persamaannya. Manusia adalah makhluk yang mempunyai persamaan terhadap Jin (Nahdiyyin, 2009: 3). Persamaan antara keduanya adalah sama-sama makhluk Allah yang memiliki kewajiban untuk menyembah dan mengabdi kepada Allah SWT.

Selanjutnya, selain memiliki persamaan memiliki kewajiban untuk beribadah kepada Allah SWT., manusia dan jin juga memiliki persamaan memiliki potensi untuk mendurhakai dan memaksiati Allah SWT.

Untuk itulah, karena dua makhluk ini sama-sama memiliki potensi untuk mendurhakai Allah SWT., Allah memperingatkan bahwa manusia dan jin tidaklah diciptakan kecuali untuk beribadah.

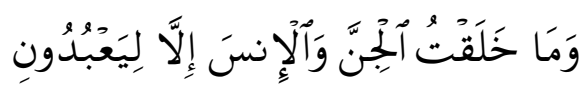

"Tidaklah kami jadikan golongan jin dan manusia kecuali untuk beribadah".

Selanjutnya manusia disebutkan oleh Allah dengan kata al-Insan. Kata alInsan yang digunakan Allah SWT menunjukkan bahwa manusia adalah makhluk yang memiliki keramahan dan memiliki kemampuan untuk mengetahui sesuatu pada level yang tertinggi. Untuk itulah manusia juga disebut dengan makhluk kultural dan makhluk sosial (Syafei, 2013: 744).
Manusia dikatakan makhluk yang ramah karena kata-kata Insan berasala dari kata Ins yang memiliki arti jinak. Sehingga makna ini sesuai dengan keberadaan manusia yang memiliki rasa ramah terhadap keadaan sosial sekelilingnya.

Sama halnya dengan Allah mengunakan kata al-Insan untuk menunjukkan manusia. Kata ini digunakan oleh Allah SWT untuk menunjukkan bahwa dalam hal penciptaannya manusia manusia mengandung dua dimensi, dimensi pertama yaitu dimensi jasmani dan dimensi kedua adalah unsur spiritual (Rizal, 2017: 224).

Kedua unsur inilah yang menjadikan manusia makhluk yang unik. Manusia memiliki rasa riang, gembira sedih. bosan rasa malas, lelah dan sebagainya yang menunjukkan bahwa manusia tersebut seorang makhluk yang memilki unsur jasmani.

Dalam Al-Quran, Allah SWT juga menggunakan kata al-Basyar untuk menunjukkan manusia. Kata al-Basyar digunakan Allah SWT. untuk mengisyaratkan bahwa penciptaan manusia melalui proses dan tahapantahapan sehingga mencapai suatu kedewasaan (Rizal, 2017: 225).

Hal ini menunjukkan bahwa proses kejadian untuk menjadi seorang manusia tidaklah terjadi secara serta merta. Akan tetapi proses kejadian manusia melalui tahapan-tahapan mulai dari nut\}fah sampai menjadi janin sampai menjadi seorang bayi, anak-anak, remaja, dan akhirnya menjadi seorang yang dewasa.

$$
\text { Etimologi al-Basyar juga }
$$
menunjukkan bahwa manusia dapat difahami sebagai makhluk yang memiliki segala sifat kemanusiaan dan keterbatasan seperti memiliki sifat lapar, haus, lelah dan lain sebaginya.. Yang intinya manusia tersebut adalah makhluk biologis (Siregar, 2017: 55). 
Maka dapat kita fahami bahwa manusia sebagi al-Basyar mengandung sebuah pengertian bahwa penciptaan manusia tersebut melalui tahapantahapan reproduksi. Dan sebagai makhluk biologis manusia tersebut berusaha untuk memenuhi kebutuhan-kebutuhan biologisnya seperti makan, minum, tidur, istirahat dan lain sebaginya.

$$
\text { Selanjutnya Allah SWT. }
$$

menggunakan kata Bani Adam untuk menunjukkan pada manusia. Kata Bani Adam ini menunjukkan semua manusia berasal dari satu keturunan atau anak cucu Adam (Nahdiyyin, 2009: 6).

Kata Bani Adam ini juga menunjukkan kepada kita bahwa manusia memiliki asal usul yang satu. Karena manusia memiliki asal usul yang satu maka manusia antara satu dan yang lainnya tidak ada perbedaan. Artinya manusia tersebut tidak berkasta dan semuanya sama dihadapan Allah SWT.

\section{Kurikulum}

Kurikulum berasal dari kata curir yang memiliki arti tempat berlari ataupun tempat berpacu. Artinya curir tersebut merupakan lintasan yang harus dilalui oleh seorang pelari sampai pelari tersebut menginjak garis finish.

Adapun menurut S. Nasution dalam Syamsul Bahri, kurikulum adalah suatu rencana pembelajaran yang disusun oleh suatu lembaga pendidikan (Bahri, 2017: 17). Rencana pembelajaran inilah yang harus dilalui oleh seorang siswa sampai siswa menamatkan pada instansi ataupun sekolah tersebut.

Adapun Hasan langulung seperti yang dikutip oleh Nur Ahid mengatakan bahwa kurikulum adalah sejumlah pengalaman yang diberikan kepada peserta didik (Ahid, 2006: 14). Pengalaman pendidikan tersebut meliputi bidang kebudayaan, tatanan sosial, olah raga dan juga seni. Pengalamanpengalaman tersebut disediakan dan difasilitasi oleh sekolah yang bersangkutan dalam rangka merubah siswa sesuai dengan tujuan dari pendidikan tersebut.

Apabila kita melihat teori kurikulum, menurut Bobbit seperti yang dikutip oleh Nur Ahid, bahwa inti dari kurikulum adalah kehidupan manusia (Ahid, 2006: 16). Artinya suatu pendidikan harus dapat mempersiapkan dan mengembangkan potensi yang ada pada diri manusia, yang mana pengembangan potensi tersebut dapat berguna bagi manusia dalam rangka menghadapi kehidupan diamasa yang akan datang.

Dalam pandangan Islam, kurikulum tidak hanya sebatas membekali siswa pada kompetensi semata. Akan tetapi lebih dari itu kurikulum juga harus dapat membekali peserta didiknya dalam rangka mempersiapkan kehidupan yang abadi nanti (Lazwardi, 2017: 103). Sehingga dalam konten kurikulum tersebut terdapat keseimbangan antara kompetensi siswa dalam menghadapi kehidupan dunia dan juga bekal dalam menghadapi kehidupan yang kekal nanti.

\section{METODE PENELITIAN}

Penelitian ini menggunakan metode library Research. Penelitian library Research atau penelitian kepustakaan adalah merupakan suatu kegiatan mengumpulkan bebrapa informasi data dan juga fakta yang terdapat dalam sumber-sumber bacaan seperti buku, majalah, jurnal dan bahan-bahan bacaan lainnya (Asmendri , 2020: 43).

Adapun menurut Zed, M. library Research adalah penelitian yang mengumpulkan data-data dari buku ataupun literatur-literatur yang ada, selanjutnnya data-data tersebut dianalisa dan diolah sedemikian rupa sehingga menghasilkan suatu kesimpulan yang baru (Zed, 2004: 3).

Data dalam penelitian ini dapat dibagi menjadi dua bagian. Yaitu data primer dan juga data sekunder. Data primer diambil langsung dari literatur- 
literatur yang secara langsung dan spesifik membahas tentang manusia dan juga kurikulum. Adapun data sekunder adalah data penunjang yang digunakan untuk memperkuat data primer tadi.

Dalam melakukan penelitian ini penulis melalui fase dan tahapantahapan. Tahapan pertama adalah mengumpulkan data-data dari literatureliteratur primer.

Pada tahap pertama peneliti membaca secara simbolik. Cara cepatnya dalah peneliti mencoba untuk membaca dengan menangkap synopsis aatupun dari abstrak dari berbagai macam tulisan kemudian dicatat pada tempat yang tertentu.

Selanjutnya penulis mencatat secara qoutasi, artinya penulis mencatat kutipan langsung tanpa adanya pengubahan struktur kata. Data juga didapat oleh penulis dengan cara paraphrase, artinya penulis menangkap inti sari dari data dengan redaksi kata yang berasal dari penulis sendiri.

Pada tahap selanjutnya mencatat secara sinoptik. Sinoptik artinya mencatat lebih pada ringkasan. Pada fase ini penulis membuat ringkasan ataupun synopsis setelah penulis membaca bagian ataupun sub bagian dari kategori data.

Setelah mencatat secara sinoptik penulis juga mencatat secara presi. Artinya penulis akan menghadapi hasil dari catatan sinoptik yang banyak. Peneliti lebih lanjut membuat catatn yang lebih padat berdasarkan hasil catatan sinoptik yang terkumpul (Sari, Milya, and Asmendri, 2020: 47).

Selanjutnya bahan ataupun data tersebut dikaji dan ditelaah secara mendalam dan digunakan sebagaimana mestinya dan digunakan sebaik-baiknya.

Setelah data didapati maka tahapan selanjutnya adalah menganalisa data yang telah didapt tersebut menggunakan analisa deskriptif. Analisa deskriptif adalah memaparkan data-data yang didapat sehingga menjadi objek suatu data.

Analisa data juga menggunakan analisi isi (content analisys). Analisis ini digunakan untuk mendapatkan data yang valid dan dapat diteliti ulang berdasarkan konteksnya. Pada proses analisis isi ini penulis melakukan proses analisa data sehingga penulis menemukan data-data yang relevan.

\section{HASIL DAN PEMBAHASAN}

Berbicara tentang pendidikan maka kita juga pasti akan membicarakan masalah kurikulum. Kurikulum adalah suatu alat untuk mengembangkan kepribadian siswa, sikap dan juga emosi serta perasaan peserta didik (Ibrahim, 2012: 3).

Kurikulum hendaklah berfungsi untuk menggali dan mengembangkan potensi-potensi yang ada pada diri manusia. Selain itu kurikulum juga harus mempunyai orientasi untuk memecahkan persoalan-persoalan yang tengah dihadapi masyarakat baik persoalan yang ada pada saat itu ataupun persoalan yang akan dihadapi oleh masyarakat pada waktu yang akan datang.

Dalam rangka mengembangkan dan menggali potensi pada peserta didik, kurikulum penyusunan kurikulum harus dilandasi oleh teori-teori tentang manusia. Hal tersebut perlu untuk dilakukan agar penyusunan kurikulun tersebut tidak bertentangan dengan kodrat manusia.

Dalam Al-Quran, untuk menunjukkan manusia Allah SWT. menggunakan term al-Ins. Terminologi alIns ini menunjukkan bahwa manusia memiliki potensi untuk baik dan juga manusia tersebut memiliki potensi untuk berbuat jelek ataupun kedurhakaan. Hal ini dijelaskan oleh Allah SWT dalam firmannya.

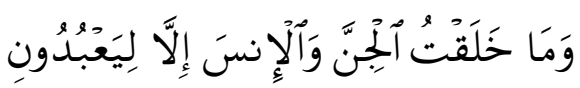


"Tidaklah kami jadikan golongan jin dan manusia kecuali untuk beribadah".

Ayat ini menjelaskan kepada kita bahwa manusia sama dengan jin. Memiliki potensi untuk ketaatan kepada Allah SWT. Disamping manusia memiliki potensi untuk taat kepada Allah SWT maka manusia juga memiliki potensi untuk membangkang dan mendurhakai Allah SWT.

Oleh karena manusia memiliki dua potensi ini, maka kurikulum hendaklah dirancang agar dapat menumbuh kembangkan potensi ketaatan tersebut dan juga menghilangkan atau meminimalisir potensi membangkang dan juga kedurhakaan kepada Allah SWT.

Untuk menyokong hal tersebut, maka kurikulum haruslah berorientasi pada penghambaan kepada Allah. Kurikulum harus dapat mendesain bahan ajar agar menjadi sebuah bahan ajar yang terintegrasi antara sains dan agama dan membawa peserta didik kepada penghambaan kepada Allah SWT.

Kurikulum haruslah dapat menciptakan bahan-bahan ajar tidak berorientasi pada kognitif semata. Lebih dari bahan ajar tersebut haruslah dapat mendekatkan peserta didiknya pada kekuasaan dan kebesaran Allah SWT. Karena dalam Islam salah satu tujuan dari kurikulum adalah menonjolkan tujuan agama dan akhlaq pada materi-materi ajar dan juga proses dari pembelajaran tersebut Marzuki, 2008: 28).

Kurikulum yang terintegrasi antara sain dan agama tersebut sebagai salah satu upaya dalam rangka menumbuh kembangkan potensi ketaatan manusia kepada Allah dan juga menghilangkan potensi durhaka kepada Allah SWT.

Dengan kurikulum yang terintegrasi maka peserta didik digiring untuk mengenal kekuasaan dan kebesara Allah SWT melalui sains yang diajarkan kepada dirinya. Tidak hanya itu interaksi-interasi yang diajarkan melalui mata pelajaran dalam kelompok humaniora juga didasari oleh semangat keislaman yang bermuara kepada ketaatan kepada Allah SWT.

Adanya kurikulum yang terintegrasi ini hendaknya dapat memberikan motivasi yang lebih kepada peserta didik untuk berakhlaq dan juga berbudi pekerti luhur baik kepada Allah SWT maupun kepada sesama manusia dan lingkungan sekitar. Dengan demikian secara tidak langsung kurikulum seperti ini telah meminimalisir potensi negatif yang ada pada peserta didik sehingga potensi positif yang dibawanya sejak lahir dapat ditumbuh kembangkan.

Dengan terpeliharanya potensi positif (baik) pada peserta didik maka kita telah mempersiapkan generasigenerasi yang handal. Suatu generasi yang dicintai Allah SWT dan generasi yang dapat memikul amanah Allah berupa menjadi Khalifatullah di muka bumi ini.

Term al-Ins juga dapat berarti jinak. Artinya bahwa manusia adalah makhluk yang jauh dari kebrutalan, akan tetapi manusia adalah makhluk yang penuh dengan keramah tamahan dan juga manusia sebagai makhluk sosial.

Tentu saja terminology al-Ins ini juga memberikan implikasi yang sangat penting dalam penyusunan sebuah kurikulum. Dikarenakan manusia sebagai makhluk sosial, maka kurikulum haruslah dapat mengakomodir penciptaan manusia sebagai makhluk sosial tersebut.

Penyusunan kurikulum juga harus mengaju pada realitas individu yang hidup ditengah-tengah masyarakat. Seluruh perubahan-perubahan sosial yang bakal terjadi pada masyarakat haruslah mendapat perhatian oleh kurikulum. Hal seperti ini perlu untuk menjadi bekal bagi peserta didik agar nantinya peserta didik tersebut dapat mengambil peran tersendiri ditengahtengah masyarakat.

Untuk itulah kurikulum haruslah dirancang bagaimana mempersiapkan peserta didik untuk dapat hidup 
ditengah-tengah masyarakat. Membekali peserta didik agar dapat berinteraksi dengan lingkungan sekitar dan bagaimana menjadikan peserta didik dapat diterima oleh lingkungan sekitarnya.

Selain itu kurikulum juga harus dapat menuntut peserta didik agar dapat menyelesaikan persoalan-persoalan sosial yang ada pada peserta didik. Dengan demikian peserta didik lebih siap untuk mengahadapi masalah-masalah sosial dan juga mampu untuk bersaing ditengah-tengah masyarakat kelak dikemudian harinya.

Allah SWT juga menggunakan term al- Basyar untuk menunjukkan manusia. Diketahui bahwa kata-kata al-Basyar menunjukkan bahwa penciptaan manusia melalui tahapan-tahapan reproduksi. Selain itu kata al-Basyar juga menunjukkan bahwa manusia adalah makhluk biologis yang membutuhkan makan, tidur memiliki rasa lelah, bosan dan lain sebagainya.

Perancang dan juga penyusun kurikulum harus memahami dan mendalami bahwa manusia adalah makhluk biologis. Maka dalam penyusunan kurikulum harus mengetahui rambu-rambu agar dalam penyusunan kurikulum tersebut tidak keluar dari konteks manusia sebagai makhluk biologis.

Untuk itulah dalam penyusunan kurikulum harus dapat mengakomodir kemampuan-kemanpuan fisikal manusia. Manusia sebagai makhluk biologis mempunyai rasa lelah, letih dan lain sebagianya.

Maka dalam penyusunan pelajaran, waktu belajar juga harus benar-benar diperhatikan agar tidak menimbulkan suatu kejenuhan pada peserta didik. Proses belajar mengajar yang begitu panjang dan menguras banyak tenaga peserta didik perlu dipertimbangkan lagi untuk diterapkan dsekolah-sekolah.
Banyak sekolah-sekolah yang menerapkan jam pelajaran yang begitu panjang kepada anak didiknya sehingga mengakibatkan kebosanan, kelelahan dan juga keletihan bagi peserta didik kita.

Rasa bosan jenuh letih akan memberikan dampak yang negatif pada proses pembelajaran dan juga prilaku peserta didik. Bisa jadi rasa malas dalam belajar disebabkan oleh begitu banyak beban pelajaran yang ditanggung oleh peserta didik kita sehingga menjadikannya acuh tak acuh dalam proses pembalajaran.

Untuk menghindari hal tersebut, maka penyusun kurikulum harus dapat berlaku arif dan juga bijaksana. Kurikulum tidak dapat memaksakan sesuatu kepada peserta didiknya yang diluar batas kemampuannya. Peserta didik adalah seorang manusia yang didalam dirinya ada aspek-aspek biologis yang harus dipenuhinya.

Dalam diri peserta didik ada perasaan lelah dan letih. Perasaan lelah dan letih ini harus diakomodir dengan memberikannya waktu istirahat yang cukup dalam rangka mengembalikan kembali konsentrasi-konsentrasi belajar yang diperlukan.

Peserta didik memiliki hak untuk bermain dan bersenang-senang dengan teman sebayanya. Maka sebagai pendidik yang menjalankan kurikulum harus dapat memberikan waktu itu. Intinya bagaimana kurikulum tersebut menjadikan proses pendidikan yang memenuhi hak-hak biologis peserta didik dan juga menjadikan pendidikan yang memanusiakan manusia.

Diatas disinggung bahwa term alBasyar menunjukkan bahwa penciptaan manusia melalui tahapan-tahapan dan juga proses. Untuk itu sebuah kurikulum dalam menyajikan materi-materi belajar juga harus memperhatikan tahapantahapan perkembangan peserta didik dan kemampuan dari peserta didik. 
Kurikulum haruslah dirancang harus dirancang sesuai dengan ciri-ciri perkembangan peserta didik , kematangan, emosi dan aspek kejiwaaan lainnya (Marzuki, 2008: 33). Demikian juga dengan materi-materi ajar yang ada pada kurikulum tersebut. Materi ajar tersebut juga harus sesuai dengan perkembangan kejiwaaan anak. Yang lebih penting bahwa materi ajar yang akan disampaikan kepada peserta didik memiliki kebermanfaatan bagi peserta didik itu sendiri.

Selanjutnya

Allah SWT. menggunakan kata Bani Adam untuk menunjukkan pada manusia. Penggunaan kata bani Adam memiliki arti anak keturunan Adam AS. Kata ini secara jelas menerangkan kepada kita bahwa semua manusia tersebut sama. Berasal dari satu keturunan dan memiliki derajat yang sama dimata Allah SWT.

Dikarenakan manusia tersebut adalah sama, maka tidak ada kemuliaan seorang manusia diatas manusia yang lain. Tidak ada kasta yang lebih tinggi dari kasta yang lain. Tidak ada golongan yang memiliki keutamaan diatas golongan yang lain.

Pada saat sekarang ini banyak sekolah-sekolah yang menawarkan bentuk dan model kurikulum. Hal ini dilakukan sebagai suatu upaya untuk menarik minat masyarakat untuk menyekolahkan putra-putrinya kesekolah tersebut.

Munculnya sekolah-sekolah unggulan memberikan sumbangan yang berarti bagi banyaknya model dan bentuk kurikulum disekolah-sekolah. Ada yang memadukan antara kurikulum Nasional dengan kurikulum internal. Dan ada juga yang mengadopsi kurikulum-kurikulum yang lainnya.

Diakui ataupun tidak masyarakat yang dapat menikmati kurikulum terpadu, kurikulum unggulan adalah masyarakat golongan menengah keatas. Untuk masyarakat golongan bawah tidak akan mendapatkan dan mencicipi manisnya kurikulum tersebut.

Demikian juga dengan fasilitas. Hanya anak-anak yang sekolah di sekolah unggulan dan terpadu saja yang akan menikmati fasilitas belajar yang baik dan mumpuni. Bagi anak yang orang tuanya kurang mampu, maka dia tidak akan mendapatkan fasilitas-fasilitas yang baik disekolah.

Merujuk pada term Bani A>dam tadi, maka pendidikan hendaknya tidaklah berkasta. Pendidikan haruslah sama dan tidak ada pengklasifikasian bahwa ini sekolah unggulan, ataupun ini kurikulum unggulan atau terpadu.

Kalaupun hal tersebut terjadi ditengah-tengah pendidikan kita, maka disinilah dituntut kearifan pemerintah untuk menghilangkan jurang pembeda tersebut dengan cara pemerataan pendidikan dan juga penyamarataan kurikulum pendidikan tersebut.

Jika hal tersebut dapat direalisasikan, maka seluruh anak bangsa akan merasakan pendidikan yang sama. Seluruh anak bangsa akan memiliki pengalaman belajar yang sama. Dan seluruh anak bangsa akan memiliki kualitas yang sama.

\section{PENUTUP}

Sebelum penyusunan sebuah kurikulum yang harus diperhatikan siapa yang akan menjalani kurikulum tersebut. Ketika kita sudah berkesimpulan bahwa yang akan menjalani kurikulum tersebut adalah manusia maka sudah sewajarnyalah untuk dapat mengakomodir apa yang ada pada diri manusia tersebut. Al-Quran menjelaskan bahwa manusia adalah makhluk sosial. Maka kurilulum haruslah membekali peserta didiknya dengan ilmu-ilmu sosial kemasyarakatan. Demikian juga Al-Quran menyebut manusia dengan kata-kata alIns. Kata ini menjelaskan bahwa manusia adalah makhluq yang memiliki dua potensi dalam dirinya, yaitu potensi baik 
dan potensi buruk. Maka kurikulum pendidikan haruslah dapat menumbuh kembangkan potensi baik yang ada pada manusia dan menghilangkan potensi buruk nya. Demikian juga dengan term alBasyar pada manusia yang memberikan implikasi pada penyusunan kurikulum. Term ini memberikan implikasi bahwa dalam penyusunan kurikulum haruslah memperhatikan aspek-aspek biologis pada manusia. Artinya kurikulum yang diterapkan pada peserta didik tersebut tidak melampaui batas sehingga menimbulkan permasalahan psikhis lainnya.

Al-Quran juga memakai term Bani Adam untuk menunjukkan pada manusia. Kata Bani Adam ini mempunyai makna bahwa manusia adalah sama derajatnya dan sama-sama keturunan. Kurikulum pendidikan harus dapat mengakomodir persamaan hak diantara manusia. Seluruh manusia berhak untuk mendapatkan pendidikan yang sama tanpa adanya diskriminasi antara yang kaya dan si miskin. Penyusunan kurikulum yang berdasarkan terminology manusia menurut Al-Quran akan dapat meminimalisir kesalahan dalam penyusunan kurikulum itu sendiri. Dengan menggunakan pendekatan terminology yang berasal dari Al-Quran, maka kurikulum tersebut akan sejalan dengan fitrah yang ada pada diri manusia itu sendiri. Sehingga kurikulum pendidikan tersebut mengakomodir nilainilai insaniyah yang ada pada manusia.[]

\section{DAFTAR RUJUKAN}

Ahid, Nur. "Konsep dan teori kurikulum dalam dunia pendidikan." Islamica: Jurnal Studi Keislaman 1.1 (2006): 12-29.

Sari, Milya, and Asmendri Asmendri. "Penelitian Kepustakaan (Library Research) dalam Penelitian Pendidikan IPA." Natural Science: Jurnal Penelitian Bidang IPA dan Pendidikan IPA 6.1 (2020): 41-53.
Asri, M. "Dinamika kurikulum di Indonesia." Modeling: Jurnal Program Studi PGMI 4.2 (2017): 192-202.

Bahri, Syamsul. "Pengembangan Kurikulum Dasar dan Tujuannya." Jurnal Ilmiah Islam Futura 11.1 (2017): 15-34.

Ibrahim, R. Kurikulum dan Pembelajaran. Jakarta: RajaGrafindo Persada, 2012.

Lazwardi, Dedi. "Manajemen kurikulum sebagai pengembangan tujuan pendidikan." Al-Idarah: Jurnal Kependidikan Islam 7.1 (2017): 119125.

Marzuki, Bakri. "Falsafah Kurikulum Dalam Pendidikan Islam." Hunafa: Jurnal Studia Islamika 5.1 (2008): 23-36.

Nahdiyyin, Khairon. "Struktur Semantik Konsep Manusia Dalam Al-Qur'an." Lingua: Jurnal Ilmu Bahasa dan Sastra 4.2 (2009).

Ritonga, Maimuna. "Politik dan Dinamika Kebijakan Perubahan Kurikulum Pendidikan di Indonesia Hingga Masa Reformasi." Bina Gogik: Jurnal Ilmiah Pendidikan Guru Sekolah Dasar 5.2 (2018).

Rizal, Syamsul. "Melacak Terminologi Manusia Dalam Alquran." At-Tibyan: Jurnal Ilmu Alqur'an dan Tafsir 2.2 (2017): 221-232.

Sari, Milya, and Asmendri Asmendri. "Penelitian Kepustakaan (Library Research) dalam Penelitian Pendidikan IPA." Natural Science: Jurnal Penelitian Bidang IPA dan Pendidikan IPA 6.1 (2020): 41-53.

Siregar, Eliana. "Hakikat Manusia (Tela'ah Istilah Manusia Versi Al-Qur'an dalam Perspektif Filsafat Pendidikan Islam)." Majalah Ilmu Pengetahuan dan Pemikiran Keagamaan Tajdid 20.2 (2017): 4867.

Subiyantoro, et.al. Pengembangan Kurikulum: Suatu Kajian Teori dan 
Praktik Pada Sekolah, Madrasah, dan Perguruan Tinggi. Yogyakarta: Samodra Ilmu, 2015.

Syafei, Isop. "Hakikat Manusia Menurut Islam." Psympathic: Jurnal Ilmiah Psikologi 6.1 (2013): 743-755.

Zed, M. Metode peneletian kepustakaan. Jakarta: Yayasan Obor Indonesia, 2004. 